\title{
Effects of Continuous Positive Airway Pressure after Oleic Acid-induced Lung Injury in Dogs
}

\author{
ALAN B. OSHER, ${ }^{(21)}$ BARBARA GOTHE, D. H. SIMMONS, B. WAYMOST, AND H. GREEN
}

Division of Pulmonary Disease, Department of Medicine and Pediatric Division of Pulmonary Disease, UCLA School of Medicine, Los Angeles, California, USA

\section{Summary}

The physiologic effects of continuous positive airway pressure (CPAP) of $5,10,15$, and $20 \mathrm{~cm} \mathrm{H}_{2} \mathrm{O}$ during spontaneous ventilation were studied in six anesthetized dogs with simulated respiratory distress syndrome (RDS) induced by iv infusion of oleic acid and in three normal controls. After oleic acid, mean $\mathbf{P a O}_{2}$ dropped to $63.6 \pm 3.1 \mathrm{~mm} \mathrm{Hg}$ while breathing $100 \%$ oxygen and mean shunt fraction was $48.3 \pm 3.0 \% . \mathrm{PaO}_{2}$ and shunt fraction improved significantly at the two highest levels of CPAP (e.g., $\mathrm{PaO}_{2} 271.3$ $\pm 41.3 \mathrm{~mm} \mathrm{Hg}$ and shunt fraction $17.8 \pm 2.2 \%$ at $20 \mathrm{~cm} \mathrm{H}_{2} \mathrm{O}$ CPAP). Mean mixed venous $\mathrm{PO}_{2}$ rose from $37.4 \pm 1.5 \mathrm{~mm} \mathrm{Hg}$ with no CPAP to $60.8 \pm 3.1 \mathrm{~mm} \mathrm{Hg}$ at $20 \mathrm{~cm} \mathrm{H} \mathrm{H}_{2} \mathrm{O}$ CPAP. Tissue oxygenation appeared to improve during CPAP, since cardiac output, oxygen delivery, and serum lactate were not significantly affected and mixed venous $\mathrm{PO}_{2}$ rose significantly. However, significant hypoventilation occurred at all but the lowest level of CPAP, mean $\mathrm{PaCO}_{2}$ rising from $44.1 \pm 1.8 \mathrm{~mm} \mathrm{Hg}$ with no CPAP to $77.6 \pm 6.8 \mathrm{~mm} \mathrm{Hg}$ at $20 \mathrm{~cm} \mathrm{H}_{2} \mathrm{O} \mathrm{CPAP}$. The hypoventilation during CPAP is consistent with increased work of breathing due to a combination of decreased lung compliance and increased dead space ventilation due to rapid, shallow breathing.

\section{Speculation}

From these studies it appears that CPAP is an effective method of improving tissue oxygenation in severe acute respiratory distress syndromes as previously speculated in clinical studies. Further studies should be directed toward the explanation for the hypoventilation response observed at higher levels of CPAP.

Spontaneous ventilation with continuous positive airway pressure (CPAP) has been widely used in the management of infants with idiopathic RDS because it raises arterial oxygen tension $\left(\mathrm{PaO}_{2}\right)(5,6)$. It has been noted clinically that hypoventilation occurs in patients requiring CPAP during spontaneous ventilation and a causal relationship has been postulated $(2,4)$. Since CPAP is being used with increasing frequency in all forms of the respiratory distress syndrome, and since other potentially important physiologic consequences of CPAP, e.g., effects on cardiac output and tissue oxygenation, have been evaluated infrequently (11), we studied the effects of CPAP on lightly anesthetized dogs with RDS induced by iv infusion of oleic acid. Oleic acid results in rapid shallow breathing and hypoxemia, heavy noncrepitant lungs, atelectasis, intraalveolar hemorrhage, interstitial edema, and hyaline membrane formation, satisfying many of the criteria for RDS (1, 8). The animal model may vary from idiopathic RDS in lacking potential vascular shunts through the foramen ovale and ductus arteriosus.

\section{MATERIALS AND METHODS}

Six mongrel dogs (18-25 kg) were anesthetized with sodium pentobarbital ( $25 \mathrm{mg} / \mathrm{kg}$ iv), followed by continuous infusion (up to $3.1 \mathrm{mg} / \mathrm{kg} / \mathrm{hr}$ iv) in saline to maintain a constant level of light anesthesia, characterized by maintenance of corneal reflexes and pupillary responses to light with absence of responses to sound or spontaneous movement of the extremities. The dogs breathed $100 \%$ oxygen spontaneously through a cuffed endotracheal tube (Portex, $11.5 \mathrm{~mm} \mathrm{ID)} \mathrm{throughout} \mathrm{the} \mathrm{experiment.}$

The following measurements were made: 1) arterial $\mathrm{pH}, \mathrm{PaCO}_{2}$, and $\mathrm{PaO}_{2}$ on samples drawn from an indwelling femoral arterial catheter (Radiometer blood gas analyzer, model PHM 71); 2) mixed venous blood gases on samples drawn from the proximal lumen of a triple lumen Swan-Ganz catheter inserted through the jugular vein into the pulmonary artery; 3) cardiac output ( $\dot{\mathrm{Q}}_{\mathrm{T}}$ ), determined by the Cardiogreen dye dilution technique (Waters densitometer; Harvard infusion/withdrawal pump, model 600 $950 \mathrm{~V})$; 4) heart rate and systemic blood pressure (BP), using the femoral arterial catheter (Statham pressure transducer, model $\mathrm{P} 23 \mathrm{Db}$ ); 5) pulmonary artery and pulmonary wedge pressure (PAP and PWP) through the lumen of the Swan-Ganz catheter (Statham pressure transducer, model P23Db); 6) transpulmonary pressure (TPP), the differential pressure between an esophageal balloon and the endotracheal tube with the dog lying in the right lateral decubitus position to avoid compression of the esophagus by mediastinal contents (Statham differential pressure transducer, model PM5); 7) tidal volume $\left(\mathrm{V}_{\mathrm{T}}\right)$ integrated from the flow signal of a Fleisch no. 1 pneumotachograph in-line with the endotracheal tube; 8 ) respiratory frequency (f) from the pneumotachograph signal; 9) mixed venous whole blood lactate and pyruvate concentrations $(12) ; 10$ ) deep body (rectal) temperature (Tele-Thermom-

$\mathrm{V}_{\mathrm{T}}, \mathrm{f}, \mathrm{TPP}, \dot{\mathrm{Q}}_{\mathrm{T}}, \mathrm{PAP}$, and PWP were recorded on an 8-channel oscilloscopic recorder (Electronics for Medicine, model DR-8). Calculated values included: 1$)$ lung dynamic compliance $\left(\mathrm{C}_{d y n}\right)$ : $\mathrm{V}_{\mathrm{T}}$ /TPP was averaged for 10 consecutive spontaneous breaths; 2 ) $\mathrm{O}_{2}$ saturation from $\mathrm{PaO}_{2}$ and $\mathrm{O}_{2}$ dissociation curve using a computer program (10); 3) shunt fraction: $\dot{\mathrm{Q}}_{\mathrm{s}} / \dot{\mathrm{Q}}_{1}=\frac{\mathrm{CaO}_{2}-\mathrm{Cc}^{\prime} \mathrm{O}_{2}}{\mathrm{Cv} \mathrm{O}_{2}-\mathrm{Cc}^{\prime} \mathrm{O}_{2}}$, where $\mathrm{CaO}_{2}, \mathrm{Cv} \mathrm{O}_{2}$, and $\mathrm{Cc}^{\prime} \mathrm{O}_{2}=\mathrm{O}_{2}$ content of arterial, mixed venous, and end-pulmonary capillary blood; 4) systemic oxygen delivery: $\mathrm{O}_{2}$ del $=\mathrm{CI} \times \mathrm{CaO}_{2}$, where $\mathrm{CI}=$ cardiac index $=$ $\dot{\mathrm{Q}}_{\mathrm{T}} /$ surface area, $\left.\mathrm{m}^{2} ; 5\right)$ pulmonary vascular resistance $(\mathrm{PVR})=$ $\left.\frac{\text { PAP - PWP }}{\dot{Q}_{\mathrm{T}}} ; 6\right)$ minute ventilation, inspired $\dot{V}_{\mathrm{I}}=\mathrm{V}_{\mathrm{T}} \times \mathrm{f} ;$ 7) base excess, Sigaard-Andersen alignment nomogram.

After making initial measurements during spontaneous ventilation, three animals, before infusion of oleic acid, received 5,10 , 15 , and $20 \mathrm{~cm} \mathrm{H}_{2} \mathrm{O}$ of CPAP in random order, each alternated with periods of zero end-expiratory pressure (0 CPAP). Measurements were made between 30 and $40 \mathrm{~min}$ after changing the amount of CPAP. All six animals then received oleic acid $(0.225$ $\mathrm{mg} / \mathrm{kg}$ or $0.28 \mathrm{ml} / \mathrm{kg}$ ) infused iv through the Swan-Ganz catheter. We used a dose of oleic acid adequate to decrease $\mathrm{PaO}_{2}$ to less than $70 \mathrm{~mm} \mathrm{Hg}$ while animals breathed $100 \%$ oxygen. Physiologic 
saline solution was infused, $500 \mathrm{ml}$ over the first $0.5 \mathrm{hr}$ and approximately 1.5 liters over the remainder of the experiment. One hour was allowed for the preparation to stabilize in three experiments, and $5 \mathrm{hr}$ in the other three. (Since no differences in responses were noted, all data were evaluated together.) Measurements were again made after the stabilization period and during administration of CPAP, similar to before oleic acid, although several measurements were made at each level of CPAP.

CPAP was administered by flowing $100 \% \mathrm{O}_{2}$ continuously through a humidifier, across a Bourn's T-piece connected to the endotracheal tube, into a 6-liter reservoir bag with a retard valve at its distal end at 2-3 times the dog's spontaneous minute ventilation to avoid rebreathing (7) (Fig. 1). The retard valve was adjusted to set the end-expiratory pressure, which was monitored with a calibrated aneroid manometer.

In order to assess the effect of oleic acid infusion and the stability of the preparation without CPAP, measurements were made on all animals breathing spontaneously with 0 CPAP before oleic acid infusion and $1.5,5,8$, and $12 \mathrm{hr}$ after oleic acid infusion. Statistical comparisons between mean values under different conditions were made using unmatched $t$-test. A level of $P<0.05$ was considered to be significant.

\section{RESULTS}

\section{EFFECTS OF OLEIC ACID INFUSION}

There was a statistically significant fall in arterial $\mathrm{pH}, \mathrm{PaO}_{2}$, $\mathrm{PviO}_{2}, \dot{\mathrm{Q}}_{\mathrm{T}}, \mathrm{C}_{\mathrm{dyn}}$, and blood pressure (Table 1) and a statistically significant increase in $\mathrm{PaCO}_{2}, \dot{\mathrm{V}}_{\mathrm{l}}$, and PVR $1.5 \mathrm{hr}$ after oleic acid infusion. Beyond the 1.5 -hr period after oleic acid infusion, no parameters changed significantly during 0 CPAP periods throughout the remainder of the experiment, and therefore all values are reported together. Thus changes subsequently observed during CPAP could not be ascribed to time-related effects of oleic acid infusion.

\section{EFFECTS OF CPAP}

Values at each of the four levels of CPAP were compared with values at 0 CPAP. The mean $\mathrm{PaCO}_{2}$ of $44.1 \pm 1.8 \mathrm{~mm} \mathrm{Hg}$ during 0 CPAP rose progressively with increasing levels of CPAP to 77.6 $\pm 6.8 \mathrm{~mm} \mathrm{Hg}$ at $20 \mathrm{~cm} \mathrm{H} \mathrm{H}_{2} \mathrm{O} \mathrm{CPAP}$ (statistically significant at 10 , $15,20 \mathrm{~cm} \mathrm{H} \mathrm{H}_{2} \mathrm{O}$ CPAP) (Fig. 2). These increases reversed completely during the 30-min period of stabilization after CPAP was discontinued (Fig. 3). Mean arterial pH decreased significantly at CPAP of 10,15 , and $20 \mathrm{~cm} \mathrm{H}_{2} \mathrm{O}$, inversely to changes in $\mathrm{PaCO}_{2}$ (Table 2). Mean $\mathrm{PaO}_{2}$ rose from $63.6 \pm 3.1 \mathrm{~mm} \mathrm{Hg}$ at 0 CPAP to $271.3 \pm 41.3 \mathrm{~mm} \mathrm{Hg}$ at $20 \mathrm{~cm} \mathrm{H}_{2} \mathrm{O}$ CPAP (statistically significant

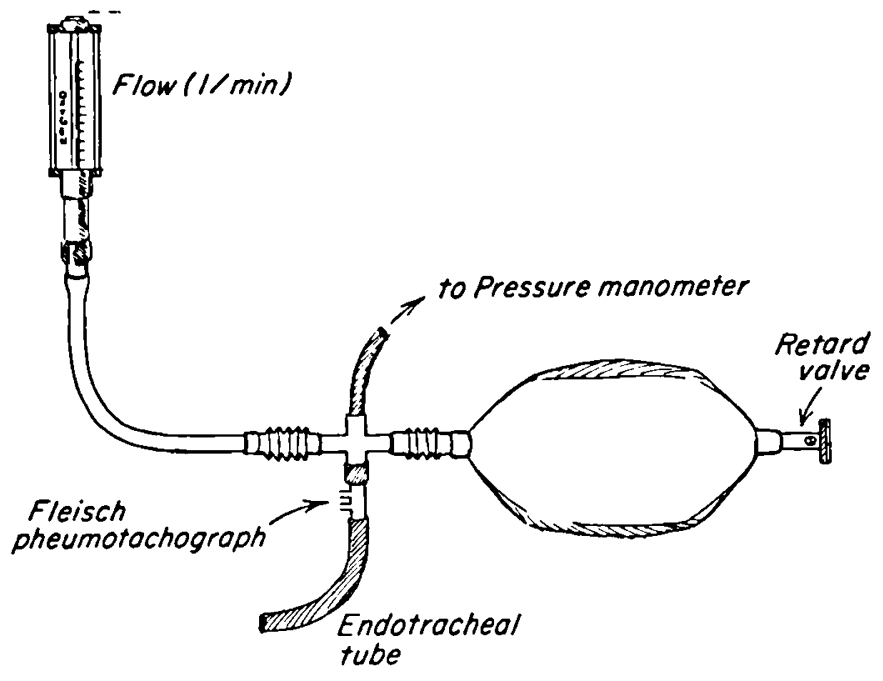

Fig. 1. Illustration of CPAP apparatus used in all experiments.
Table 1. Respiratory and circulatory effects of oleic acid infusion

\begin{tabular}{|c|c|c|}
\hline & $\begin{array}{c}\text { Before } \\
\text { oleic } \\
\text { acid }\end{array}$ & $\begin{array}{l}\text { After } \\
\text { oleic } \\
\text { acid }\end{array}$ \\
\hline $\mathrm{PaCO}_{2}, \mathrm{~mm} \mathrm{Hg}^{\prime}$ & $38.5 \pm 2.4$ & $44.1 \pm 1.8^{2}$ \\
\hline $\mathrm{pH}^{\prime}$ & $7.38 \pm 0.02$ & $7.20 \pm 0.01^{2}$ \\
\hline$\dot{\mathrm{V}}_{\mathrm{l}}$, liters $/ \mathrm{min}^{1}$ & $7.54 \pm 0.9$ & $24.3 \pm 1.5^{2}$ \\
\hline $\mathrm{PaO}_{2}, \mathrm{~mm} \mathrm{Hg}^{1}$ & $473.0 \pm 19.4$ & $63.6 \pm 3.1^{2}$ \\
\hline $\mathrm{PṽO}_{2}, \mathrm{~mm} \mathrm{Hg}$ & $63.9 \pm 5.2$ & $37.4 \pm 1.5^{2}$ \\
\hline $\mathrm{C}_{\mathrm{dyn}}, \mathrm{ml} / \mathrm{cm} \mathrm{H} \mathrm{H}_{2} \mathrm{O}^{\prime}$ & $67.0 \pm 8.0$ & $14.0 \pm 1.0^{2}$ \\
\hline$\dot{Q}_{r}$, liters $/ \mathrm{min}^{1}$ & $2.91 \pm 0.33$ & $1.57 \pm 0.06^{2}$ \\
\hline Arterial blood pressure, $\mathrm{mm} \mathrm{Hg}^{1}$ & $152.0 \pm 2.8$ & $130.6 \pm 2.4^{2}$ \\
\hline $\begin{array}{l}\text { Pulmonary vascular resistance, } \mathrm{mm} \\
\mathrm{Hg} / \mathrm{liter} / \mathrm{sec}^{1}\end{array}$ & $3.2 \pm 0.3$ & $9.7 \pm 0.7^{2}$ \\
\hline $\begin{array}{l}\text { Whole blood lactate conc, } \mathrm{mEq} / \mathrm{li}- \\
\text { ter' }\end{array}$ & $1.8 \pm 0.3$ & $1.9 \pm 0.2$ \\
\hline Temp, rectal, ${ }^{\circ} \mathrm{C}^{\prime}$ & $38.1 \pm 0.2$ & $38.7 \pm 0.6$ \\
\hline
\end{tabular}

${ }^{1}$ Mean \pm SEM.

${ }^{2} P<0.05$, statistically significant difference from before oleic acid mean values.

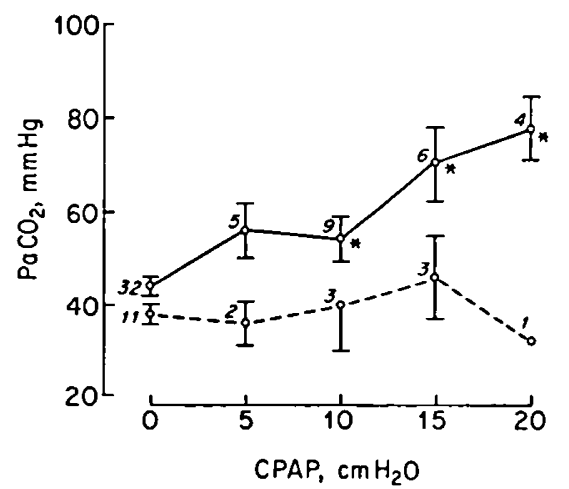

Fig. 2. Effect of CPAP on $\mathrm{PaCO}_{2}$ in animals with severe oleic acidinduced lung injury $(-)$ and in normal animals $(---)$. Values are expressed as mean \pm SEM. The number at each level of CPAP refers to the number of measurements made. Asterisk indicates a statistically significant difference $(P<0.05)$ from mean 0 CPAP values.

at 10,15 , and $20 \mathrm{~cm} \mathrm{H}_{2} \mathrm{O}$ ) (Fig. 4). Mean $\mathrm{PṽO}_{2}$ rose from $37.4 \pm$ $1.5 \mathrm{~mm} \mathrm{Hg}$ at $0 \mathrm{CPAP}$ to $60.8 \pm 3.1 \mathrm{~mm} \mathrm{Hg}$ at $20 \mathrm{~cm} \mathrm{H} \mathrm{H}_{2} \mathrm{O}$ CPAP (statistically significant at 10,15 , and $20 \mathrm{~cm} \mathrm{H}_{2} \mathrm{O}$ ) (Fig. 4). Mean $\dot{Q}_{\mathrm{s}} / \dot{Q}_{1}$ decreased with increasing CPAP, the change was statistically significant at 10,15 , and $20 \mathrm{~cm} \mathrm{H}_{2} \mathrm{O}$ CPAP (Fig. 4). Mean $\dot{\mathrm{V}}_{1}$ decreased significantly at CPAP of 10,15 , and $20 \mathrm{~cm} \mathrm{H}_{2} \mathrm{O}$ characterized by a decrease in $\mathrm{V}_{\mathrm{T}}$ (Fig. 5 ).

Mean $\dot{Q}_{\mathrm{T}}$ did not change significantly from 0 CPAP at any level of CPAP (Table 2). Changes in mean arterial blood pressure were statistically significant at 10,15 , and $20 \mathrm{~cm} \mathrm{H}_{2} \mathrm{O}$ CPAP (Table 2). Mean $\mathrm{O}_{2}$ delivery, whole blood lactate concentrations, $\mathrm{C}_{\mathrm{dyn}}$, and PVR did not change significantly from 0 CPAP at any of the levels of CPAP studied (Table 2).

In the three animals studied before oleic acid lung injury there was no significant difference between $\mathrm{PaCO}_{2}$ values at 0 CPAP and at 5-20 $\mathrm{cm} \mathrm{H}_{2} \mathrm{O}$ (Fig. 2). The respiratory pattern remained normal in contrast to the rapid shallow breathing observed in the animals after oleic acid lung injury (Fig. 5).

\section{DISCUSSION}

$\mathrm{PaO}_{2}$ increased significantly during CPAP of 15 and $20 \mathrm{~cm}$ $\mathrm{H}_{2} \mathrm{O}$, changes similar to those previously reported in clinical trials with CPAP in treatment of idiopathic RDS $(2,4-6)$. Cardiac output did not fall significantly at any level of CPAP studied, in contrast to animal studies using continuous positive pressure breathing (CPPB) with similar levels of end-expiratory pressure 
(PEEP), probably because CPAP increases intrathoracic pressure less than does comparable levels of $\operatorname{PEEP}(9,17)$. Since $\mathrm{PaO}_{2}$ rose and $\dot{Q}_{\mathrm{T}}$ did not change, $\mathrm{O}_{2}$ delivery increased. Predictably, $\mathrm{PvO}_{2}$ rose progressively with increasing levels of CPAP. Thus, tissue oxygenation is likely to have improved with CPAP, since changes

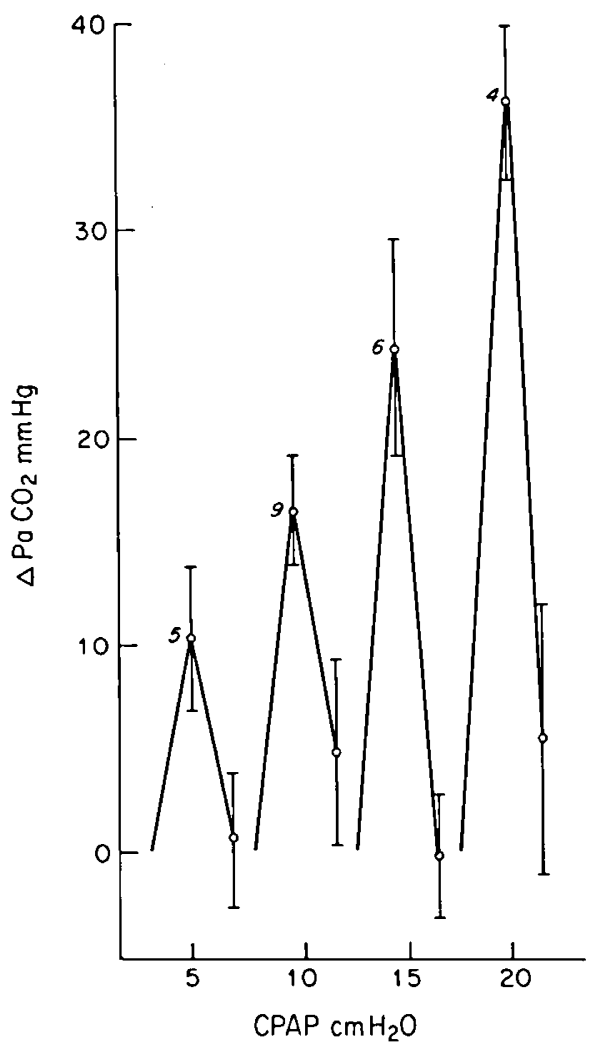

Fig. 3. Effect of CPAP and removal of CPAP on $\mathrm{PaCO}_{2}$ in animals with severe oleic acid-induced lung injury. Values are expressed as mean \pm SEM. The number at each level of CPAP refers to the number of measurements made. $\Delta$ indicates change from previous mean observed values.

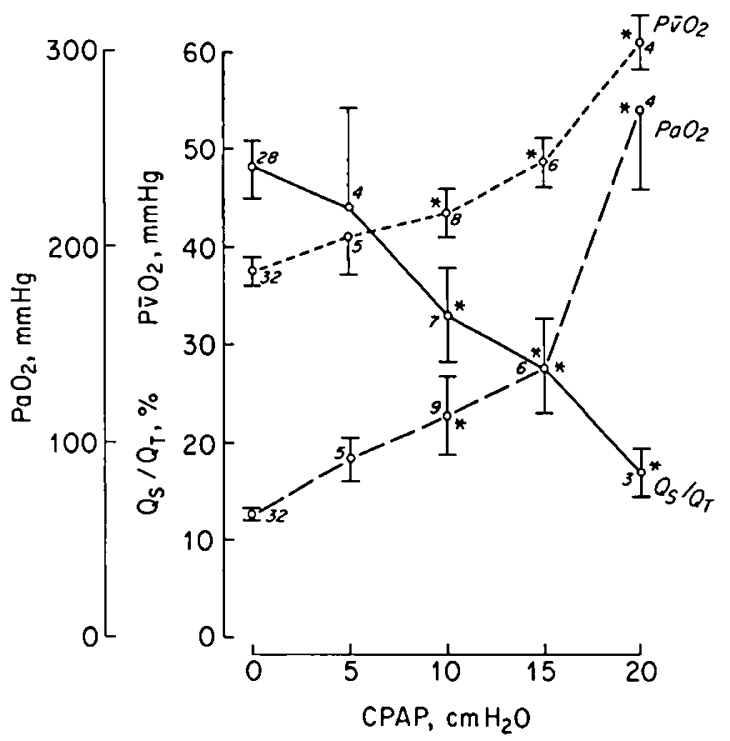

Fig. 4. Effect of CPAP on $\mathrm{PaO}_{2}, \mathrm{P}_{\mathbf{v}} \mathrm{O}_{2}$, and $\dot{\mathrm{Q}}_{3} / \dot{\mathrm{Q}}_{1} \%$ in animals with severe oleic acid-induced lung injury. Values are expressed as mean \pm SEM. The number at each level of CPAP refers to the number of measurements made. Asterisk indicates statistically significant difference $(P<0.05)$ from mean 0 CPAP values.

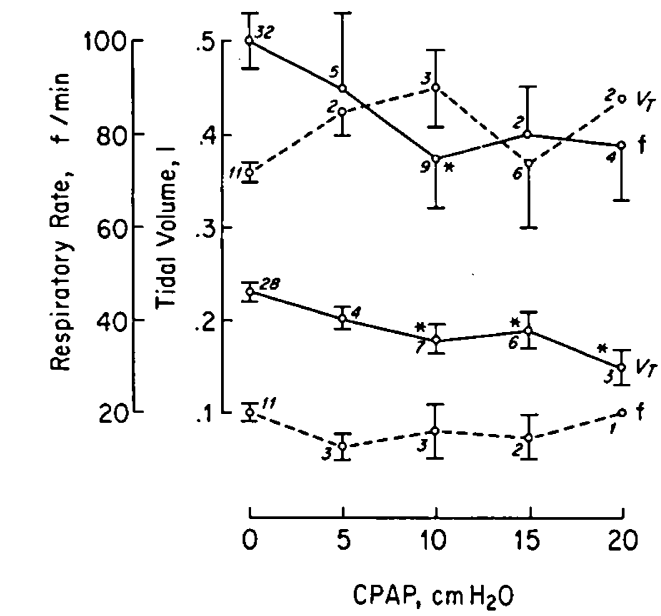

Fig. 5. Effect of CPAP on respiratory rate and tidal volume in animals with severe oleic acid-induced lung injury $(-)$ and in normal animals $(--)$. Values are expressed as mean \pm SEM. The number at each level of CPAP refers to the number of measurements made. Asterisk indicates statistically significant difference $(P<0.05)$ from 0 CPAP values.

in $\mathrm{P}_{\mathrm{v}} \mathrm{O}_{2}$ are thought to reflect changes in tissue $\mathrm{PO}_{2}(16)$. The fact that whole blood lactate concentration did not change indicates that there was no significant redistribution of blood flow resulting in hypoperfusion of some tissues.

Significant findings not previously reported in clinical studies of effects of CPAP are the observations that hypercapnea proportional to the level of CPAP occurs during CPAP in a model of severe $\mathrm{RDS}$, and that the increase in $\mathrm{PaCO}_{2}$ is immediately reversible upon discontinuing CPAP. During any level of CPAP in three animals before oleic acid infusion significant hypoventilation did not occur, indicating that hypoventilation does not occur with CPAP alone but only with the additive effect of oleic acid lung injury. The mechanism of the difference has not been studied but is presumably related to the increased work of breathing after oleic acid injury. This could be related to changes in compliance and in respiratory rate and dead space ventilation.

Possible explanations for the hypercapnea after lung injury during CPAP include the following.

\section{REBREATHING OF EXHALED CO. IN SEMICLOSED ANESTHESIA SYSTEM}

Significant rebreathing from the anesthesia bag was unlikely, because $\mathrm{O}_{2}$ flow across the opening of the endotracheal tube was 2-3 times the animal's minute ventilation. In several animals flow rates of $\mathrm{O}_{2}$ were varied from 1-6 times the animal's minute ventilation without significantly affecting $\mathrm{PaCO}_{2}$, suggesting that flow rates were not a factor in producing hypercapnea. Third, the carbon dioxide tension in the anesthesia bag was less than $8 \mathrm{~mm}$ $\mathrm{Hg}$ in all experiments, much less than the maximal changes in $\mathrm{PaCO}_{2}$ observed, and could thereafter not possibly account for more than a small fraction of the hypercapnea noted.

\section{INCREASED WORK OF BREATHING}

CPAP could potentially increase the work of breathing per unit alveolar ventilation by increasing lung volume and shifting ventilation to a higher portion of the pressure-volume curve, where compliance is lower, and by increasing anatomic dead space (13, 18). However, measured dynamic compliance did not change significantly at any level of CPAP. Furthermore, $\dot{V}_{1}$ decreased with increasing CPAP, so that the work of breathing was not increased by an increase in volume of ventilation, raising the question of whether increasing $\mathrm{PaCO}_{2}$ during CPAP could be related to the work of breathing. The possibility remains for two reasons. First, static compliance almost certainly increased with increasing lung volume. Second, CPAP has been reported to 


\begin{tabular}{|c|c|c|c|c|c|}
\hline & \multicolumn{5}{|c|}{$\mathrm{cm} \mathrm{H}_{2} \mathrm{O}$ CPAP } \\
\hline & 0 & 5 & 10 & 15 & 20 \\
\hline$\overline{\mathrm{pH}}$ & $7.20 \pm 0.01$ & $7.12 \pm 0.05$ & $7.12 \pm 0.03^{2}$ & $7.03 \pm 0.04^{2}$ & $7.00 \pm 0.03^{2}$ \\
\hline $\mathrm{Q}$, liters $/ \mathrm{min}^{1}$ & $1.57 \pm 0.06$ & $1.43 \pm 0.16$ & $1.43 \pm 0.06$ & $1.44 \pm 0.17$ & $1.35 \pm 0.20$ \\
\hline Arterial blood pressure, $\mathrm{mm} \mathrm{Hg}^{1}$ & $130.6 \pm 2.4$ & $127.4 \pm 4.2$ & $121.3 \pm 3.9^{2}$ & $120.3 \pm 5.0^{2}$ & $116.5 \pm 4.3^{2}$ \\
\hline $\mathrm{O}_{2}$ delivery, $\mathrm{ml} / \mathrm{min}^{1}$ & $291 \pm 19$ & $279 \pm 44$ & $297 \pm 25$ & $315 \pm 22$ & $290 \pm 43$ \\
\hline Whole blood lactate, $\mathrm{mEq} /$ liter' & $1.91 \pm 0.19$ & $2.08 \pm 0.43$ & $1.74 \pm 0.52$ & $2.25 \pm 0.47$ & $1.88 \pm 0.46$ \\
\hline $\mathrm{C}_{\mathrm{dyn},} \mathrm{ml} / \mathrm{cm} \mathrm{H}_{2} \mathrm{O}^{1}$ & $14.0 \pm 1.0$ & $15.0 \pm 1.0$ & $14.0 \pm 2.0$ & $16.0 \pm 3.0$ & $18.0 \pm 2.0$ \\
\hline Pulmonary vascular resistance, $\mathrm{mm} \mathrm{Hg} / \mathrm{liter} / \mathrm{sec}^{1}$ & $9.7 \pm 0.7$ & $10.8 \pm 2.1$ & $9.4 \pm 1.2$ & $8.3 \pm 1.7$ & $12.0 \pm 2.5$ \\
\hline
\end{tabular}

1 Mean \pm SEM.

${ }^{2} P<0.05$, statistically significant difference from mean O CPAP values.

produce active expiration (3). Since under normal conditions the major respiratory work is inspiratory, the work of breathing might be increased during CPAP in spite of the fact that $C_{d y n}$ did not change.

\section{EFFECT ON STIMULATION OF PULMONARY REFLEXES}

Since stretch receptor discharge has been reported to inhibit ventilation in normal dogs (15) by a direct effect on the respiratory center, it is possible that the increased airway pressure and/or lung volume during CPAP could depress ventilation by a direct effect of increasing stretch receptor activity on the respiratory center or by limiting $\dot{V}_{T}$ (with unchanged $f$ ) due to increased stretch receptor stimulation during inspiration at higher lung volumes (exaggerated inspiratory-inhibitory reflex).

Lysons and Cheney (11) studied the effects of 5,10 , and $15 \mathrm{~cm}$ $\mathrm{H}_{2} \mathrm{O}$ positive end-expiratory pressure in dogs before and after oleic acid lung injury, breathing $100 \%$ oxygen spontaneously through a nonrebreathing valve with its expiratory line immersed under water. Although their system differed from ours in that positive airway pressure was not applied during the entire respiratory cycle, the effects on $\mathrm{PaO}_{2}, \mathrm{P}^{2} \mathrm{O}_{2}, \mathrm{PaCO}_{2}$, and shunt fraction were similar. Lysons' mean $\mathrm{PaCO}_{2}$ before lung injury was $55 \pm 4$ $\mathrm{mm} \mathrm{Hg}$, as compared to our mean of $39 \pm 2 \mathrm{~mm} \mathrm{Hg}$. The lower $\mathrm{PaCO}_{2}$ in our study may have resulted from the inspiratory assist of our system. Their results differed from ours prior to oleic acid injury in that there was a significant increase in $\mathrm{PaCO}_{2}$ at $15 \mathrm{~cm}$ $\mathrm{H}_{2} \mathrm{O}$ only, and a decreased respiratory rate at 5,10 , and $15 \mathrm{~cm}$ $\mathrm{H}_{2} \mathrm{O}$. The rise in $\mathrm{PaCO}_{2}$ at $15 \mathrm{~cm} \mathrm{H}_{2} \mathrm{O}$ in Lysons' experiments might be because ventilatory loading has a greater effect on $\mathrm{PaCO}_{2}$ the greater the initial $\mathrm{PaCO}_{2}$ and presumed respiratory depression (unpublished observations, this laboratory).

In Lysons' study following oleic acid lung injury cardiac index fell significantly at $15 \mathrm{~cm} \mathrm{H}_{2} \mathrm{O}$ and respiratory rate fell significantly at all levels of CPAP with no significant change in $\dot{V}_{T}$, in contrast to our study in which there was no change in cardiac output and a significant fall in $\mathrm{f}$ only at $10 \mathrm{~cm} \mathrm{H}_{2} \mathrm{O}$ and a significant fall in $\dot{\mathrm{V}}_{\mathrm{T}}$ at 10,15 , and $20 \mathrm{~cm} \mathrm{H}_{2} \mathrm{O}$. There is no clear explanation for the differences between our results and those of Lysons with respect to f or $\dot{V}_{\mathrm{T}}$ before or after lung injury. Our animals received almost double the oleic acid dose of Lysons' $(0.15 \mathrm{ml} / \mathrm{kg})$, and with zero end-expiratory pressure our animals had a mean $\mathrm{PaO}_{2}$ of $63.6 \pm$ $3.1 \mathrm{~mm} \mathrm{Hg}$, as compared to $95 \pm 13 \mathrm{~mm} \mathrm{Hg}$ in Lysons' experimental group. The more severe lung injury and resultant greater hypoxemia in our group may have stimulated ventilation or changed pulmonary reflexes activity.

\section{REFERENCES AND NOTES}

1. Ashbaugh, D. G., and Uzawa. T.: Respiratory and hemodynamic changes after injection of free fatty acids. J. Surg. Res., 8: 417 (1968).

2. Belenky, D. A., Orr, R. J., Woodrum, D. E., and Hodson, W. A.: Is continuous transpulmonary pressure better than conventional respiratory management of hyaline membrane disease? A controlled study. Pediatrics, 58: 800 (1976).

3. Bishop, B., and Bachofed, H.: Comparative influence of proprioceptors and chemoreceptors in the control of respiratory muscles. Acta Neurobiol. Exp., 33: 381 (1973).

4. Cohen, $\mathrm{M}$. L.: $\mathrm{CO}_{2}$ retention during continuous positive airway pressure. Pediat. Res., 7: 426/198 (1973).

5. Gregory, G. A., Kitterman, J. A., Phibbs, R. H., Tooley, W. H., and Hamilton, W. K.: Treatment of the idiopathic respiratory-distress syndrome with continuous positive airway pressure. N. Engl. J. Med., 284: 24 (1971).

6. Gupta, J. M., van Vliet, P. K. J., Vonwiller, J. B., and Fistk, G. C.: Positive airway pressure in respiratory distress syndrome. Med. J. Aust.. I: 90 (1974).

7. Harrison, G. A.: The effect of the respiratory flow pattern on rebreathing in a Tpiece system. Brit. J. Anesthesiol., 36: 206 (1964).

8. Jefferson, N. D., and Necheles, H.: Oleic acid toxicity and fat embolism. Proc. Soc. Exp. Biol. Med., 68: 248 (1948).

9. Jones, R. L., and King, E. G.: Evaluation of positive end-expiratory pressure in hypoxemic dogs. J. Appl. Physiol., 35: 213 (1973).

10. Kelman, G. R.: Digital computer subroutine for the conversion of oxygen tension into saturation. J. Appl. Physiol., 21: 1375 (1966).

11. Lysons, D. F., and Cheney, F. W.: End-expiratory pressure in dogs with pulmonary edema breathing spontaneously. Anesthesiology, 37: 518 (1972).

12. Marbach, E. P., and Weil, M. H.: Rapid enzymatic measurement of blood lactate and pyruvate. Clin. Chem., 13: 314 (1967).

13. Marshall, R.: Relationships between stimulus and work of breathing at different lung volumes. J. Appl. Physiol., 17: 917 (1962).

14. Peltier, L. F.: Fat embolism. III. The toxic properties of neutral fat and free fatty acids. Surgery, 40: 665 (1956).

15. Phillipson, E. A., Fishman. N. H., Hickey, R. F., and Nadel, J. A.: Effect of differential vagal blockade on ventilatory response to $\mathrm{CO}_{2}$ in awake dogs. J. Appl. Physiol., 34: 759 (1973).

16. Tenney, S. M.: A theoretical analysis of the relationship between venous blood and mean tissue oxygen pressures. Resp. Physiol., 20: 283 (1974).

17. Uzawa, T., and Ashbaugh, D. G.: Continuous positive-pressure breathing in acute hemorrhagic pulmonary edema. J. Appl. Physiol., 26: 426 (1969).

18. Wiebe, H., Brooks, J. G., and Gregory, G. A.: The effect of continuous positive airway pressure (CPAP) on lung function in infants with the respiratory distress syndrome (RDS) [Abst.]. Pediat. Res., 9: 402 (1975).

19. Dr. B. Waymost was supported by USPHS Training Grant HL 05917.

20. This research was supported in part by USPHS Grant HL 12458.

21. Requests for reprints should be addressed to: A. B. Osher, M.D., Pediatric Pulmonary Disease Division, UCLA School of Medicine, 10833 Le Conte Avenue, Los Angeles, CA 90024 (USA).

22. Received for publication August $8,1977$.

23. Accepted for publication November 16, 1977. 